\title{
Impact of Additional Physical Activity Program on Motor Abilities Development in School Children
}

\author{
Vanja Popovic ${ }^{1}$, Fitim Arifi $^{2}$, Boris Zarkovic ${ }^{3}$, Marin Corluka ${ }^{4}$ \\ 'Independent Researcher, Podgorica, Montenegro, 2University of Tetovo, Faculty of Physical Education and Sport, Tetovo, North Macedonia, \\ ${ }^{3}$ University of Novi Sad, Faculty of Sport and Physical Education, Novi Sad, Serbia, ${ }^{4}$ University of Mostar, Faculty of Mathematics and Science \\ Education, Mostar, Bosnia and Herzegovina
}

\begin{abstract}
The aim of this study is to determine there is a statistically significant difference in motor ability indicators in children of early school age before and after the defined experimental process. The total number of subjects is 40 and the subjects was divided into two subsamples: a subsample of boys $(n=20)$ with an average age of $6.20 \pm 0.34$ years and a subsample of a girls $(n=20)$ with an average age of $6.16 \pm 0.62$ years. All subjects were participants in the program of the sports school of the children fitness centre Smart Gym from Podgorica. Subsamples were subjected to an experimental process lasting 8 weeks. Immediately before and after the experimental process, motor abilities were measured using the following 10 tests: $5 \mathrm{~m}$ sprint, $10 \mathrm{~m}$ sprint, standing long jump, polygon backwards, bent arm hang, sit and reach, climbing and descending, stork balance stand test, sit ups, and throw and catch test. The results of the study show that the experimental process was successful in improving the polygon backwards, forward deep bend and throw and catch test in boys and stork balance stand test, sit ups and throw and catch test in girls. Such a program could improve the working methodology in all sport schools throughout Montenegro.
\end{abstract}

Keywords: Motor Skills, Children, School Age, Montenegro

\section{Introduction}

In practice, it is one of the priority tasks in work with children to care about their optimal growth and development (Masanovic, 2019; Banjevic, 2020). In part of motor structure and its development, early school age is a particularly sensitive period for children's development (Horvat, 2010; Djoric \& Vukicevic, 2020). It is clear that impact of motor development is crucially important for total children's development in early school age, but there are situations when many think that this could be developed of itself at children, what is the problem of physiology. According to Horvat, Babic \& Miholic (2013) impact the level of many physical exercise stimulus on children's motor progressively declining as they get to a grown up stadium, which is often called in practise as a critical development phase. As addition to this, Paušić (2007) says that one of the critical morphological-motoric periods is age 6 to 7 , when a child starts school. In this growing up period, speed and coordination in all its shapes develop rapidly, while sensible development period of other motoric abilities is less visible in this age, but their development also speeds up by systematic exercise (Bala, 2007). When it comes to affection on development of motoric abilities which are genetically more caused (such as speed), in sensible periods it must be especially careful and achieve a certain foundation in order to keep working on it (Bjelica, 2005a; 2005b; Arifi, Alaj, Metej, Sermaxhaj, \& Nebiu, 2015). This type of problem is interesting at preschool and early school children's age, mostly because this growing up period is characteristic by strong growth and development of all anthropometric points, so it is possible to expect different latent structure of anthropometric characteristics and motoric abilities compared with older age (Katić, Pejčić, \& Viskić-Štalec, 2004). In that way, certain movement characteristics of early school children's age (6 and 7 years), compared to older age, may be described as the child is moving more harmoniusly and more safely, and it gets outlines of mo-

\section{Correspondence:}

\section{Montenegro V.Popovic}

Sport Independent Researcher, Simona Ivanova bb, 81000 Podgorica, Montenegro E-mail: vanja.vanja.popovic@gmail.com 
toric structures which will follow him many years on (Bala, 2009).

At early school children's age, during physical exercise classes, it is rarely taken care of all latent motoric abilities, which child in that age period should practise constantly (Likic, Bajramovic, \& Vranesic-Hadzimehmedovic, 2018; Vasiljevic, Bjelica, Popovic, \& Gardasevic, 2015). Caused by that reason, parents often choose additional sports activities or sports schools, so that child would better develop its motoric potential and fulfill their own movement necessity (Gardasevic, Bjelica, Popovic, \& Vasiljevic, 2015).

Through researches so far, it is clear to see that in early school age were obtained positive results of efficiency of motoric abilities in two time points (Gardašević, Georgiev, \& Bjelica, 2012; Masanovic, 2020). However, kinesiologists are still striving for discovery of more functional and more purposeful programs, due to exploitation of critical development periods of motoric abilities at children's of different ages and knowledge levels of movement structures. Through sports schools, through as diverse as possible with sports contents it is tried to give adequate stimulant to motoric ability development at children from 3 to 12 years old. In that are mostly included several basic sports systems (gymnastics and athletics) with supplementation of elements from sports games and martial sports.

This research determines exercise effects on motoric abilities development program of children in early school age (efficiency for this research created working program), therefore, determines values of changes level at certain motoric abilities in a period of 8 weeks and as if it is any at all. Applicable and efficient exercise programs are always needed and welcome so it is justified to assume that this research will be useful for science and praxis.

\section{Methods}

\section{Procedure}

The presented research is of longitudinal character, and the examination was performed at the beginning (initial state) and at the end (final state) of the experimental process. Experimental process lasted for 8 weeks and it was conducted in the form of modern physical education classes. Children had trainings 2 times per week, and program is made in way that in one week children exercise identical trainings, one training point was for learning and second was for improvement. Entire program of the experimental process is shown in addition.

\section{Participants}

In this research sample of respondents consisted of boys and girls of early school age. Total number of respondents is 40 and respondents was divided into two subsamples: subsample boys $(n=20)$ of average age of $6.20 \pm 0.34$ and subsample girls $(n=20)$ of average age of $6.16 \pm 0.62$. All respondents were attendants of a sports school program at children's fitness centre Smart Gym from Podgorica, and beside this, they ordinarily went to school and had physical education classes. Also, beside the sports school program, respondents were not included in any other extracurricular sports programs.

Based on research type, the sample of respondents included only children who have done complete measurement treatment and complete experimental treatment between two time points. It is necessary to remind that all parents gave their assent and they had the ability to resign their participation in this research at any point.

\section{Instruments}

For motoric ability assessment of children were used standard motoric test (Šoše \& Rađo, 1998), so this research was conducted through following motoric tests, which by standardization were adapted to testing 6 years old students: sprint $5 \mathrm{~m}(\mathrm{sec})$; sprint $10 \mathrm{~m}$ ( $\mathrm{sec})$; standing long jump ( $\mathrm{cm}$ ); polygon backwards ( $\mathrm{sec})$; bent arm hang $(\mathrm{sec})$; sit and reach (cm); climbing and descending (sec); stork balance stand (sec); sit ups (repetitions); throw and catch (repetitions).

All measurements were done by students of the Faculty for Sport and Physical Education with help of trainer from children's fitness centre. All measurements were done according to standardized methods (Metikoš, Franjo, Hofman, Pintar, \& Oreb 1989), according to younger age categories modification (Bala, 2009).

\section{Statistical analysis}

The data obtained through the research were processed using descriptive and comparative statistical procedures. For each variable, central and dispersion parameters have been processed. The significance of the differences between time points for both respondents was determined by Student t-test for small samples, with statistical significance of $p<0.05$. Data were prepare in statistic package „STATISTICA 12.0 for Windows“.

\section{Results}

In Table 1 there is descriptive parameters review for all examined variables of motoric abilities of boys in both time points (initially and finally), also there is review of statistical significance of difference in results between initial and final state of boys.

Table 1. Descriptive data and difference between motoric abilities at initial and final measurement of boys $(n=20)$

\begin{tabular}{lcccc}
\hline & Initial measurement & Final measurement & & \\
Variable & Mean \pm SD & Mean \pm SD & t - value & Sig \\
\hline Sprint $5 \mathrm{~m}$ & $1.64 \pm 0.20$ & $1.53 \pm 0.14$ & 1.90 & .062 \\
Sprint 10m & $2.77 \pm 0.29$ & $2.62 \pm 0.22$ & 1.89 & .071 \\
Standing long jump & $120.70 \pm 18.09$ & $129.50 \pm 19.17$ & -1.49 & .144 \\
Polygon backwards & $23.99 \pm 8.32$ & $18.34 \pm 4.99$ & 2.61 & $.008^{*}$ \\
Bent arm hang & $14.22 \pm 18.24$ & $17.48 \pm 18.75$ & -0.56 & .578 \\
Sit and reach & $36.80 \pm 10.30$ & $44.15 \pm 12.53$ & -2.03 & $.047^{*}$ \\
Climbing and descending & $27.29 \pm 9.36$ & $22.63 \pm 6.79$ & 1.80 & .081 \\
Stork balance stand & $26.64 \pm 19.80$ & $33.94 \pm 19.12$ & -1.19 & .243 \\
Sit ups & $15.30 \pm 4.94$ & $18.05 \pm 4.88$ & -1.77 & .080 \\
Throw and catch & $2.30 \pm 1.92$ & $3.90 \pm 1.37$ & -3.03 & $.000^{*}$ \\
\hline
\end{tabular}

Note: Mean - arithmetic mean; SD - standard deviation; $\mathrm{t}$ - value - strength difference between groups; Sig - statistical significance of differences; ${ }^{*}$ - statistical significance $p \leq 0.05$ 
Review of Table 1 clearly reveals that at 3 variables, in the final state is visible statistically significant difference of values compared to initial state. It is interesting that two variables assessed primarily coordination in different shapes. At throw and catch variable it is determined statistically significant difference at $\mathrm{p}=0.00$ level of statistical significance, and negative $\mathrm{t}$-value of -3.03 , which means that respondents on final testing of assess- ment of throwing and catching ball against the wall made better result compared to initial state for average 1.60 repetitions.

Variable polygon backwards showed difference between two time points at $\mathrm{p}=0.01$ level of statistical significance with 2.61 positive t-value. With this it is clearly visible, as with review of Figure 1 that boys at final measurement were for average $5.66 \mathrm{sec}$ better than at initial testing.

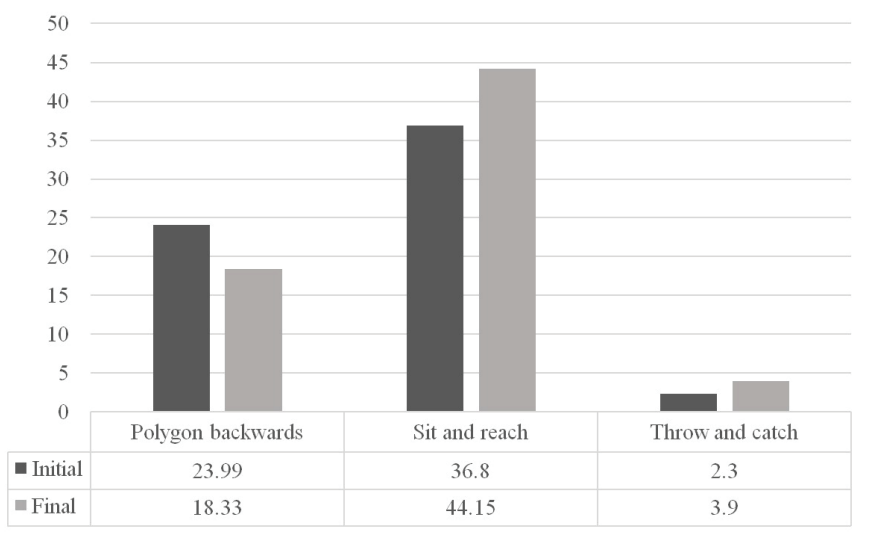

FIGURE 1. Statistically significant differences between two time points at boys

On the other side one variable for flexibility assessment, sit and reach, showed difference at $\mathrm{p} \leq 0.05$ level of statistical significance, where respondents at final measurement had an average result of $44.14 \mathrm{~cm}$ compared to initial state when they had average result of $36.80 \mathrm{~cm}$. It is visible that boys significantly improved flexibility through this experimental program, while also the biggest improvement was noticeable at variables for coordination in space and around hands coordination assessment. So that this experimental training program gave certain statistically significant improvements at boys.

In Table 2 there is review of descriptive parameters for all conducted variables of motoric abilities for girls in both time points (initially and finally), also there is review of statistical significance of differences between results of initial and final state of girls.

Table 2. Descriptive data and difference between motoric abilities at initial and final measurement of girls $(n=20)$

\begin{tabular}{lcccc} 
& Initial measurement & Final measurement & & \\
Variable & Mean \pm SD & Mean \pm SD & t - value & Sig \\
\hline Sprint $5 \mathrm{~m}$ & $1.62 \pm 0.11$ & $1.63 \pm 0.27$ & -0.23 & 0.821 \\
Sprint $10 \mathrm{~m}$ & $2.81 \pm 0.15$ & $2.75 \pm 0.17$ & 1.06 & 0.299 \\
Standing long jump & $112.45 \pm 18.31$ & $122.2 \pm 15.54$ & -1.82 & 0.082 \\
Polygon bacwards & $24.21 \pm 8.71$ & $20.25 \pm 5.98$ & 1.67 & 0.104 \\
Bent arm hang & $13.97 \pm 17.35$ & $19.07 \pm 17.29$ & -0.93 & 0.361 \\
Sit and reach & $40 \pm 8.95$ & $46.15 \pm 11.91$ & -1.85 & 0.068 \\
Climbing and descending & $27.29 \pm 9.66$ & $24.25 \pm 7.19$ & 1.13 & 0.272 \\
Stork balance stand & $29.92 \pm 18.63$ & $42.13 \pm 17.76$ & -2.12 & $0.040^{*}$ \\
Sit ups & $16.2 \pm 3.91$ & $18.95 \pm 4.71$ & -2.01 & $0.045^{*}$ \\
Throw and catch & $2.1 \pm 1.97$ & $3.4 \pm 1.54$ & -2.33 & $0.031^{*}$ \\
\hline
\end{tabular}

Table 2 review, which contains information about differences of motoric abilities between initial and final state at girls, reveals that at three variables is noticeable statistically significat difference. Difference at $\mathrm{p}=0.03$ level of statistical significance is visible again at variable throw and catch, which means this experimental process had positive impact at around hands coordination at both subsamples. Also, by further reviewing Table 2 and graphics, it is clearly visible that at the final testing girl for average 1.30 repetitions made better results compared to initial state.

Unlike boys, at girls differences are shown at variables for balance and repetitive strength of abdominal wall assessment. At variable Stork balance stand test difference is determined at $\mathrm{p}=0.04$ level of statistical significance, where respondents at final testing had average result of $42.13 \mathrm{sec}$ which is significant improvement compared to initial state of average $29.92 \mathrm{sec}$. There is conclusion that many exercises for balance keeping through the polygon system of work, lead to adequate effect and improve this ability at girls.

Also in the variable Sit-up for girls, with a significant difference at the level of $\mathrm{p}=0.05$ statistical significance, the initial result on the final test was improved by an average of 2.75 repetitions, which was an average of 16.20 repetitions. This was achieved with $\mathrm{t}$-value of -2.33 which indicates results improvement.

As at both subsamples there were statistical significant differences of motoric abilities, it may be claimed for sure that experimental process had positive impact on motoric abilities improvement of respondents. 


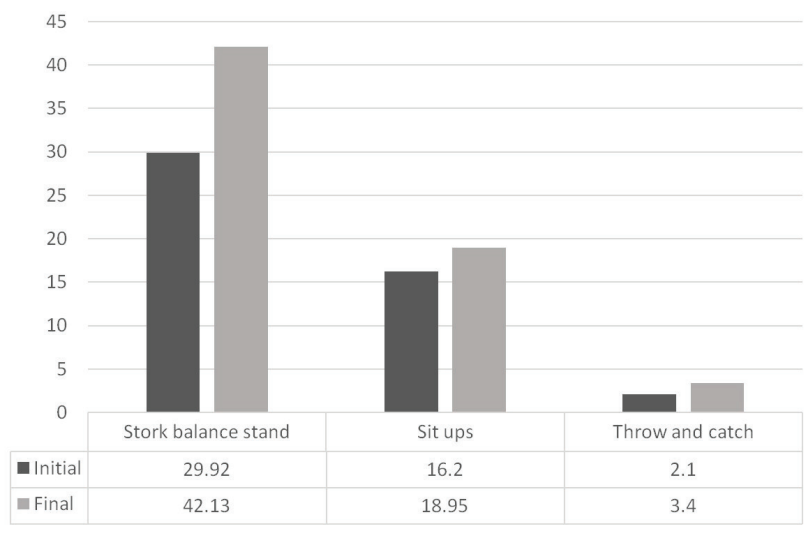

FIGURE 2. Statistically significant differences between time points at girls

\section{Discussion}

One of the aims of profession is to reveal the most purposeful programs for anthropological status improvement at children (Sindik et al., 2017). They would be used as base for further work, because at already developed motoric structure, later may be built more, of course if we maximum use sensitive periods of development of certain motoric abilities (Stijepic \& Nicin, 2007). In this case, experimental treatment was conducted for 8 weeks, where directly before and after experimental treatment were conducted motoric abilities testing.

In part of this research which observed boys, it is clearly seen that at three examined variables (polygon backwards, sit and reach and throw and catch tests) was found statistically significant difference between two time points, while at seven variables (sprint 5m, sprint 10m, jump forward, bent arm hang, climbing and descending, Stork balance stand and sit ups tests) there was not visible statistically significant difference between initial and final state.

In part of this research which observed girls, it is visible that at three examined variables (Stork balance stand, sit ups and throw and catch tests) is found statistically significant difference between two time points, while at other seven variables (sprint $5 \mathrm{~m}$, sprint 10m, jump forward, polygon backwards, bent arm hang, sit and reach and climbing and descending tests) there was not found statistically significant difference between initial and final state at girls.

When it comes to individual certain motoric abilities, level of their improvement because of applied experimental program compared to initial state at boys and girls, it may be concluded that they are noticeable at results of test which examined coordination but are not noticeable in result of test for speed valuation. Out of this, it is concluded that there are indicators that this program has positive impact on coordination at childrens early school age, while it did not make a significant difference when it comes to speed.

Besides that, improvement of certain motoric abilities through usage of defined experimental program are noticeable at respondents of one gender while they are not noticeable at other gender. So for example at boys it is noticeable that there is improvement of results test for flexibility examination, while at girls it was not the case. The reason for this could be the higher initial level of flexibility that girls naturally possess (Trautner et al., 2005). Opposite of that, at girls there is improvement at examination of parameters of strength and balance, while there are not ones at boys. Which is no surprise, because previous research emphasizes that the increase in strength in boys is higher only after the age of 12 (Parker, Round, Sacco, \& Jones, 1990), and that girls have a lower center of gravity than boys due to the specific body structure which can affect on balance (Bubanj, 1997).
With everything said so far, it may be concluded that the experimental program is quality and purposeful, given that statistically significant difference was found in motoric abilities indicators between initial and final state of motoric abilities of boys and girls of early school age through defined experimental process.

Recommendation for further researches is that training process could be further modified, or it could be added another training point during one week. Also this program was comprehensive with elements which hypothetically could impact at every motoric ability, but could be even better results if focus was at only one motoric ability. Anyways, this research should be useful as starting point for further research of this kind, especially in this part of children sports extracurricular engagement.

Significance of this research reflects in immediate application of results in practise, especially in planning and programing further training processes, as well as modification of current ones. This research determined how efficient this program is for motoric abilities development, at children of early school age. Especially this kind of research could improve working programs of sports schools through Montenegro, and could give adequate information to professors of physical education about transformation processes and trends of motoric abilities development, in order to adequate follow new dynamics of profession improvement. Of course, with research of this kind, could gain popularisation of this kind of extracurricular physical activities. This study results will for sure help for further development of plan and program as in this sports school as in private children sports and educational institutions.

\section{Acknowledgments}

The authors wish to thank the their attendants and their parents, and to colleagues from children's fitness centre Smart Gym from Podgorica for their cooperation,

\section{Conflict of Interest}

The authors declare that there is no conflict of interest.

Received: 1 October 2020 | Accepted: 15 December 2020 | Published: 18 January 2021

\section{References}

Arifi, F., Alaj, I., Metaj, Z., Sermaxhaj, S., \& Nebiu, J. (2015). Canonic relations of anthropometric and motor space between students as football players and non football players. Sport Mont, 13(43-44-45), 256-261.

Bala, G. (2007). Antropološke karakteristike i sposobnosti predškolske dece. Novi Sad: Univerzitet u Novom Sadu, Fakultet sporta i fizičkog vaspitanja.

Bala, G. (2009). Relationships between anthropological characteristics and abilities of preschool children. Istraživačka monografija, Beograd: Old Commerce.

Banjevic, B. (2020). Differences in Some Morphological Characteristics between Students of Younger School Age from Niksic and Mojkovac. Journal of Anthropology of Sport and Physical Education, 4(2), 15-18.

Bjelica, D. (2005a). Osnovi antropomotorike teorija. Sport Mont, 3(5), 95-96. 
Bjelica, D. (2005b). Razvoj tjelesnih sposobnosti mladih fudbalera mediteranske regije u crnoj gori uticajem sportskog treninga. Sport Mont, 3(6-7), 208-222.

Bubanj, R. (1997). Osnovi primenjene biomehanike u sportu. Niš: Filozofski fakultet.

Djoric, N., \& Vukicevic, V. (2020). Nutritional Status of Young School Children in a Rural Environment in Srem District. Journal of Anthropology of Sport and Physical Education, 4(2), 19-21. doi: 10.26773/jaspe.200404

Gardasevic, J., Bjelica, D., Popovic, S., \& Vasiljevic, I. (2015). Attitudes of parents of preschool children towards the frequency and aspects of the use of computers. Journal of Physical Education and Sport, 15(3), 479

Gardašević, J., Georgiev, G., \& Bjelica, D. (2012). Qualitative changes of basic motor abilities after completing a six-week training programme. Acta Kinesiologica, 6(1), 70-74.

Horvat, V. (2010). Relacije između morfoloških i motoričkih dimenzija te spremnosti za školu djece predškolske dobi. Neobjavljena doktorska disertacija, Zagreb: Kineziloški fakultet, Sveučilišta u Zagrebu.

Horvat, V., Babić, V., \& Miholić, S. J. (2013). Gender Differences in Some Moto Abilities of Preschool Children. Croatian Journal of Education, 15(4), 959980.

Katić, R., Pejčić, A., \& Viskić-Štalec, N. (2004). The Mechanism of Morphological-Motor Funcioning in Elementary School Female First-to Fourth Graders. Collegium antropologicu, 28(1), 261-299

Likic, S., Bajramovic, I., \& Vranesic-Hadzimehmedovic, D. (2018). Relationship between morphological characteristics and dynamic running parameters in the case of boys aged 10-12 years. Journal of Anthropology of Sport and Physical Education, 2(1), 27-30.

Masanovic, B. (2019). Gender and Age Differences in Attitudes of Serbian Pupils toward Physical Education Lessons and their Preferences Regarding Lesson Organisation. Croatian Journal of Education, 21(1), 213-231.
Masanovic, B. (2020). Prescribed Physical Education Syllabus vs. Modified Physical Education Syllabus Containing Proprioception Exercises: Comparative Study. International Journal of Applied Exercise Physiology, 9(1), 149-158.

Metikoš, D., Franjo, P., Hofman, E., Pintar, Ž., \& Oreb, G. (1989). Mjerenje bazičnih motoričkih dimenzija sportaša. Zagreb: Fakultet za fizičku kulturu.

Parker, D.F., Round, J.M., Sacco, P., \& Jones, D.A. (1990). A cross-sectional survey of upper and lower limb strength in boys and girls during childhood and adolescence. Annals of human biology, 17(3), 199-211.

Paušić, J. (2007). Konststrukcija i vrednovanje mjernih postupaka za procjenu tjelesnog držanja u dječaka dobi od 10 do 13 godina. Neobjavljena doktorska disertacija, Zagreb: Kineziološki fakultet, Sveučilišta u Zagrebu.

Sindik, J., Mandić, G., Zenić, N., Zovko, I., Stanković, V., Savić, Z, Djokić, Z \& Kondrič, M. (2017). Comparison of Psychological Skills, Athlete's Identity, and Habits of Physical Exercise of Students of Faculties of Sport in Four Balkan Countries. Montenegrin Journal of Sports Science and Medicine, 6(1), 13-28.

Stijepic, R., \& Nicin, D. (2007). Sensitive periods research in the precision with the elementary schoolboys. Sport Mont, 5(12-13-14), 204-215.

Šoše, H., \& Rađo, I. (1998). Mjerenje u kineziologiji. Sarajevo: Fakultet sporta i tjelesnog odgoja.

Trautner, H.M., Ruble, D.N., Cyphers, L., Kirsten, B., Behrendt, R., \& Hartmann P. (2005). Rigidity and flexibility of gender stereotypes in childhood: Developmental or differential? Infant and Child Development: An International Journal of Research and Practice, 14(4), 365-381.

Vasiljevic, I., Bjelica, D., Popovic, S., \& Gardasevic, J. (2015). A critical review of parents of preschool children related to computer use. Journal of Physical Education and Sport, 15(4), 692. 